\title{
Factors Influencing the Participation in Customers' Loyalty Programmes: The Case of Croatia
}

\author{
Ivan Kovač, Dora Naletina, Dunja Brezović
}

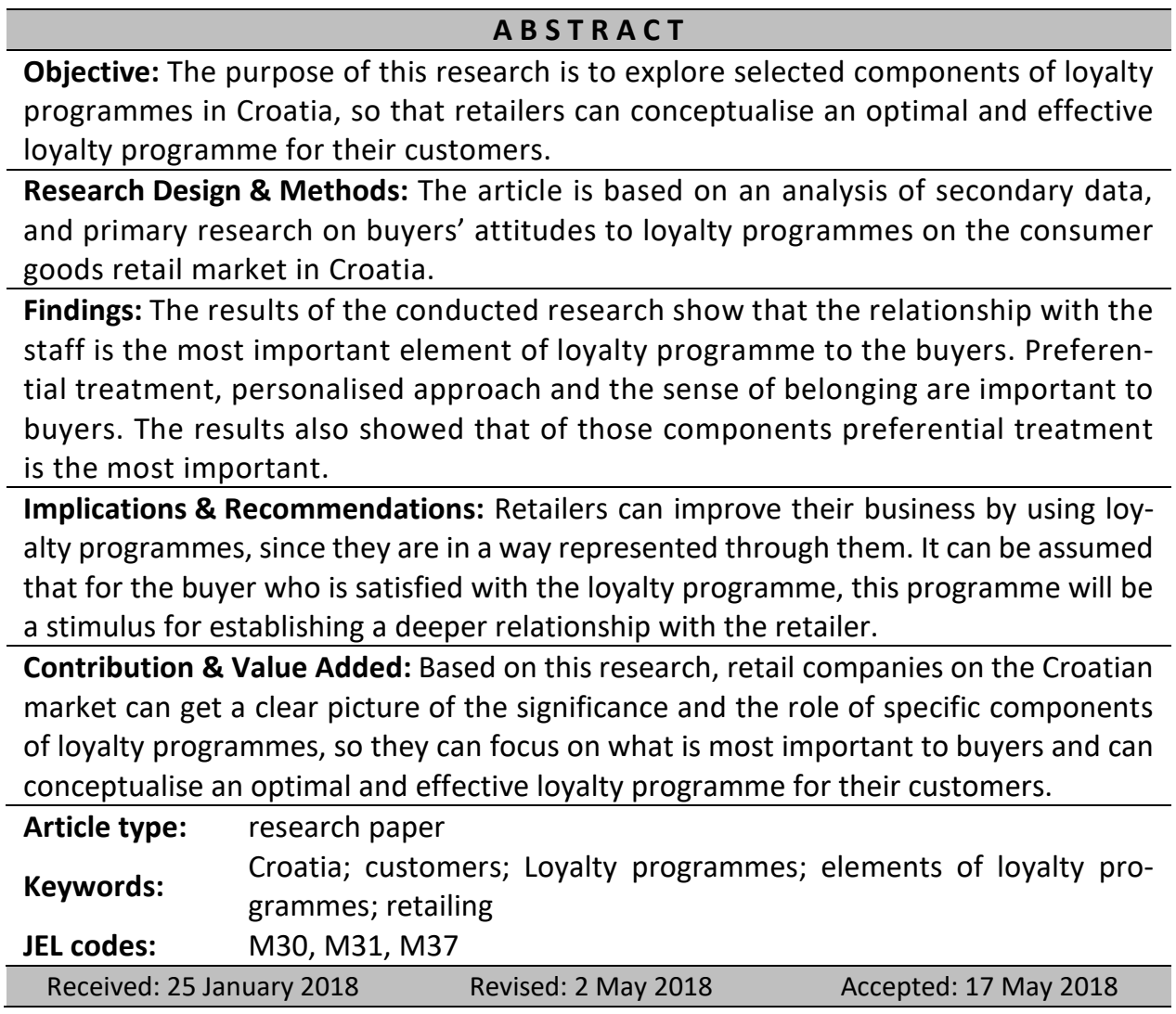

\section{Suggested citation:}

Kovac, I., Naletina, D., \& Brezovic, D. (2018). Factors Influencing the Participation in Customers' Loyalty Programs: The Case of Croatia. Entrepreneurial Business and Economics Review, 6(2), 185-199. https://doi.org/10.15678/EBER.2018.060210 


\section{INTRODUCTION}

Looking for a way to attract customers or keep the existing ones, retailers will often implement loyalty programmes into their business. Those programmes offer customers the possibility of collecting credits which they can then trade for specific products after a certain period. Meyer-Waarden et al. (2013: 202) define a loyalty programme as "a set of activities that offers conveniences to customers, based on the evidence of loyalty". Retailers can use them as competitive advantage, in such a way that they will offer financial and non-financial benefits as well, like special treatment and product and service adjustment to the customer's needs. The role and existence of loyalty programmes in retail are to provide some very important information to the customer. Namely, loyalty programmes bring benefits to the customer, but the retailer certainly benefits from them, too, possibly even more than the customers. It is a well-known fact that loyalty programmes are included in the customers' databases, and in this case, they are a retailer's treasure. Based on the collected data, identification and segmentation of customers is conducted. Besides, a retailer will make a connection with the buyer by using the information from the database (previous purchases, personal data) to address the buyer and for promotional reasons, but at an individual level. Although it seems that loyalty programmes are just a system of giving rewards to customers, their more valuable role is to study the customers and create relationships with them. Over the past years, loyalty programmes have become 'the key component of customer relationship management, creating a critical role in the development of relationships with the customers, stimulating the use of goods and services, and keeping the customer' (Omar et. al., 2011). To create loyalty, a retailer must make a connection with the buyer. In line with that, Dorotic, Bijmolt and Verhoef (2012: 231) list 'creating connections with the customers' as one of the basic goals of loyalty programmes. However, it is clear that through loyalty programmes they try to increase the consumption level a customer holds at a retailer's.

This article will thoroughly explore some of the components of loyalty programmes, which previous research has deemed important for the efficiency of loyalty programmes, and customers' attitudes to these components on the Croatian consumer goods market. In order to achieve the set goals of this article, the secondary and primary research was conducted. In order to confirm the findings of the previous research on loyalty programmes, a detailed overview of domestic and foreign scientific literature from the research area was carried out. After the literature review, and the description of the applied methods, the results of the conducted primary research are presented with the aim of validating research hypotheses. The structure of the programmes is analysed according to the components conceptualised by Breugelmans et al., (2015, p. 128), those being: membership application, types (structure) of the programmes, credit structure, relationship and communication with the buyers and reward structure. Further, the survey results are discussed and the final chapter presents conclusions and implications and recommendations for practice.

The research results, i.e. stated opinions, wishes or priorities of the customers regarding the factors most often characterised as being crucial for the success of a loyalty programme, can be useful for retailers in the improvement of their loyalty programmes. 


\section{LITERATURE REVIEW}

To what extent loyalty programmes actually contribute to the business is still rather unclear. This question cannot be precisely answered, because it depends on the retailer's strategy. If a retailer's goal is to make profit, and the loyalty programme is just another way of generating it, the segmentation of customers is also needed, alongside the strategy. The change in the buyers' behaviour, i.e., more frequent purchases at a specific retailer, according to Agudo et al. (2012, pp. 1335-1336), is influenced by the quality of the provided service, the customers' trust to the retailer and the customers' attitude towards loyalty programmes. The result of a proper strategy are satisfied customers who can become loyal. Hajdukiewicz (2016, p. 160) links customers' satisfaction to a positive influence on the reputation and image of the company, and thinks this type of promotion is 'one of the best loyalty indicators'. Xie and Chen $(2013$, p. 472) state that 'loyal customers usually expect better products and services for their commitment'. Meyer-Waarden et al. (2013, pp. 220-221) propose that the retailers should offer rewards according to the customers' motivation and shopping preferences.

Previous research focused mainly on the rewards that contribute most to customers' loyalty and on approaches which are most valuable to gain loyalty (e.g. Kim et al., 2013; Bojei et al., 2013), or on the impact of the programmes on the satisfaction from the store (Sreejesh et al., 2016). Bakhtieva (2017, pp. 472-473) in her research has analysed B2B digital marketing strategy as a framework for assessing digital touchpoints and increasing customer loyalty based on Austrian heating, ventilation and air conditioning industry companies. She has developed new framework which aims to increase customer loyalty and focuses on channels/touchpoints, assets, skills, audience and customer journey. Szwajcy (2016, pp. 102104 ) in her paper analysed, on the example of Polish banking sector, corporate reputation and customer loyalty as the measures of competitive enterprise position. The results of conducted research have confirmed weak relationship between reputation and loyalty. As well, results have confirmed the existence of positive dependence between the loyalty level and market share. Although a lot of this research has positive outcomes for the retailers, the question remains whether the confirmation of the customers' satisfaction from the store, as the consequence of the participation in a loyalty programme can actually translate into the success of the loyalty programme. The answer to this question depends on the way in which the retailer perceives the success of the loyalty programme. As Rudle-Thiele (2005, p. 492) marked, loyalty should be considered as more than one thing. The influence on retailers' business results these programmes carry can only be assumed. By analysing previous research on loyalty programmes, Dorotic, Bijmolt and Verhoef $(2012$, p. 230) state that it is difficult to determine the influence of loyalty programmes on the retailers' profit, because it is hard to get the information on the costs of implementing them. Most retailers use loyalty programmes as defensive tools because their competitors also provide them (Julian et al., 2016, p. 1191). 'The main reason for launching many loyalty programmes is the competition' (Dowling and Uncles, 1997, p. 71). This statement is supported by the research of Solarova (2015), which showed two new loyalty programmes by different retail chains which emerged on the market at approximately the same time.

Besides wrong reasons for launching loyalty programmes, their failure can be prompted by unprofitable members - the buyers. Xie and Chen $(2013$, p. 468) divided 
them into three categories: those who look for good deals (deal seekers), inactive buyers and those who switch between programmes (switchers). Customers who are deal seekers will not make the connection and collect credits, but will rather agree to a lower value reward, just to make use of the opportunity. Inactive buyers are those who are not really interested in loyalty programmes, and most often shop only once. Programme switchers often change between programmes, i.e. their motivation for staying in the programme is not high. A retailer can contribute to the success of loyalty programmes in different ways. Besides creating a quality rewarding concept and capturing customers with personalised approach, retailers have to think about the reputation and impression they make on customers who will use the loyalty programme. Omar et al. (2011) prove the importance of an honest and sincere approach to the customer, and claim that loyalty programmes characterised by fairness and honesty result in customers' pleasure and trust to the programme. Brashear-Alejandro et al. (2016, p. 1193) think that a retailer can invite buyers to try out new products, and in that way show them that they are accepted and their opinion is valued. Customer satisfaction is important for yielding success with loyalty programmes. Sreejesh et al. (2016, p. 891) state that 'customers satisfaction is the necessary element for keeping customers loyal'. Bearing in mind that loyalty plays an important role in the creation of loyalty programmes, it is crucial to perceive all the factors that lead to customers' positive assessment of a loyalty programme, i.e. their satisfaction.

Out of seven dimensions for assessing service quality in loyalty programmes (psychological aspects, programme policy, rewards, personalisation, usefulness of information, communication quality, courtesy/serviceability), in the research by Omar et al. (2011), programme policy has proved to be the most important factor in the evaluation of the service quality. Simple programme policy implies easy enrolment, recalculation and checking of credits, and is very important to buyers. Noble et al. (2014) conducted research on restrictive policies of claiming rewards in a loyalty programme, like setting the date until the coupon/discount can be redeemed. The results of this research are equal to those of previous research (e.g. Dowling \& Uncles, 1997), and they suggest that restrictions on money rewards harm the owners of the programmes. The literature lists two terms, i.e. mechanisms connected with credit collection, one of which relates to the credit threshold, and the other with rewarding. The credit pressure effect refers to adjustment of/increase in the number of purchases so that the buyer could reach or cross the set threshold. By approaching the threshold, that effect becomes more expressed. It can also be called the credit threshold effect, because the existence of that very threshold causes certain changes in buyers' behaviour. The other mechanism is the rewarded behaviour effect, and its goal is to entice more frequent purchases with rewarding. It can be said that its success depends on the internal motivation of the buyer. If a buyer has been shopping in line with his shopping habits, i.e. standard products he always buys, and in that way has earned a reward, then the rewarding should encourage repeated purchases at the same retailer's. But if a customer buys something just to win a reward, the reward effect is questionable. The rewarded behaviour effect depends on the reward as well. If the buyer is not satisfied with the reward, the effect will not bring much result.

Buyers' opinions are various, tastes and interests are different. This is the reason why a perfect loyalty programme concept, which would meet everybody's expecta- 
tions, cannot be created. Most customers, especially on the Croatian market, will participate in a loyalty programme solely with the aim to save money, due to the lack of financial resources. Some buyers simply enjoy the very process, shopping is not monotonous; they look forward to going through catalogues and clipping out coupons. Their priority is not to save money, but to have fun. It is therefore difficult to specify what the buyers want from a loyalty programme. It would be ideal if there were no limitations, and if the buyers could always choose for themselves on what to spend the collected credits. But, on the other hand, if the requirements of the customers were always met, loyalty programmes would make no sense because there would be no profit for the retailer. That is why it is important to find balance, provide the customers with the minimum of what most of them want and expect.

\section{MATERIAL AND METHODS}

The relationship and communication with the buyers is the component of loyalty programmes that has been thoroughly researched, primarily on the question how much the relationship with the staff is important to buyers to be satisfied with the programme. The research by Vesel and Zabkar (2009) showed that the quality of interaction between the staff and the buyers influences the satisfaction in the buyers. Buyers' satisfaction from all the services from the retailers and their employees will probably translate into the satisfaction from the programme. The satisfaction from the entire service can result in the creation of a relationship with the retailer, which will probably have a positive impact on the attitudes towards the loyalty programmes of the same retailer. This loyalty is important because there can be a situation when the buyer will not be interested in the conveniences offered through loyalty programmes, but if a company has created a connection with them, there is a possibility that because of this connection, they will stay in the programme and will not look for other conveniences with the competitors. It is unquestionable that the relationship between the sales staff and the buyers influences buyers' feelings and opinions on loyalty programmes and the store. Therefore, for the establishment of a good relationship, it is necessary for the staff to be trained (selection, education, rewarding), and what is more important, to become acquainted with facts on the buyers' needs for a tight relationship with the employees. Omar and Musa (2011) confirm the importance of the interaction of the sales staff with the customers. Bojei et al. (2013) established that the emphasis on the customer service has a positive impact on staying in the programme, i.e. retaining the customers, and that those customers who receive good service will continue to buy from the same retailer. In line with that, for the purpose of this research, we constructed the following hypothesis:

H1: In loyalty programmes, the relationship with the sales staff is important to the buyers.

The rewards within loyalty programmes can be observed according to: the form of the reward (material or immaterial), connection with the product (direct or indirect) and time of rewarding (immediate or postponed). Material rewards (hard benefits) are financial benefits and other tangible rewards like discounts, financial rewards, coupons and gifts. Immaterial rewards (soft benefits) are benefits that evoke certain emotions and psycho- 
logical states in buyers. Those are: personalisation, adjustment, special treatment, hedonistic benefits (entertainment and exploration), and emotions as the consequence of those benefits, and they are combined under the term 'symbolic benefits'. Soft benefits are often characterised as the means for differentiation. Some soft benefits are listed by Julian et al. (2016, p. 1195): invitations for special occasions, sending catalogues, personal/individual treatment, and adjustments of the products or services. To achieve a better effect in buyers, individuality plays the key role in soft benefits. The goal is to make the customers feel welcome, informed on all current deals, that they gladly return to the same retailer, and with the individual approach a retailer shows respect and acknowledges their loyalty. Individuality can boost the value of all immaterial benefits and it is achieved by a direct contact with the buyer, via e-mail, invitations, gift cards etc., where great importance can be attached to addressing them with the full first name and surname. Individual or personalised approach is the second determinant in the research by Omar and Musa (2011), following the quality of interaction with the staff, which influences the evaluation of the quality of service in a loyalty programme. Bearing in mind that the same authors have proved that service quality influences the loyalty of the buyers more than satisfaction, it is important to pay attention to this statement. The positive influence of personalisation on retaining customers was also confirmed by Bojei et al. (2013). It is therefore, for the purpose of this research, necessary to formulate the following hypothesis:

H2: For the buyers, personalised approach in loyalty programmes is important.

Personalisation was divided by Bojei et al. (2013, p. 174) into three levels: 1. Operative level (refers to collecting information from the customers, so they can be offered unique ideas). 2. Interpersonal level (it implies the recognition of the buyers by name, improvement of the relationship between the staff and the buyers.) 3. Organisational level (it refers to an original approach to the buyer, e.g. via personalised birthday cards.

Actually, the literature often points out to the problem of the imitation of loyalty programmes. But, within a programme, there is also the issue of equivalence, imitation and no innovation. Special attention of retailers or preferential treatment are also considered one of immaterial (soft) benefits. It can be described as the unification of hard (e.g. discounts only for members) and soft (e.g. informing the buyers about the deals) benefits. This treatment relates to 'any type of special or preferential treatment that buyers receive via the membership in a loyalty program' (Brashear-Alejandro et al., 2016, p. 1192). The aim is to show the buyers that they are considered 'special' and distinguished from others who are not members. Huang (2015) points to the relationship between the special treatment and the loyalty of customers in Taiwan. The author claims that when a buyer recognizes some marketing investments of the retailer, special treatment is recognized as the most important tool, and it is followed by communication between the buyer and the staff, and tangible rewards - gifts and coupons. The buyers will feel gratitude and it is probable that the future purchases at the retailer's will be increased. For the purpose of the previously mentioned research in Croatia, we formulated the following hypothesis:

H3: For the buyers, 'preferential treatment' in loyalty programmes is important.

Hedonistic benefits are connected with entertainment a loyalty programme offers via credit collecting, trading them for rewards, and the sense of pleasure and achievement that arises in the buyers. The research made by Sreejesh et al. (2016, p. 888) showed that the loyalty programmes generate satisfaction from the store, and claim 
that different hedonistic elements (e.g. interesting games or competitions customers want to join) in loyalty programmes can help to turn this satisfaction into love and loyalty towards the retailer. Based on the research that showed a great impact of hedonistic benefits on loyalty in certain programmes, Kim et al. (2013, p. 109) suggest retailers that they should pay more attention to the fun factor in loyalty programmes. Therefore, for the purpose of this article, the following hypothesis is constructed:

H4: Buyers want loyalty programmes that include fun elements.

The feelings the individual approach evokes in customers, or 'symbolic benefits' can be the consequence of the very participation in a loyalty programme, so the members can feel accepted, i.e. the sense of social belonging, because they think they share the same interests with other members. Positive feelings and experience will be most often connected with the service that was provided in the store, where the key role is played by the staff. The sense of status and social belonging is also the consequence of immaterial benefits. With the hierarchical loyalty programmes (multi-tiered programmes), buyers on higher levels enjoy the status of a special customer. Recognition by the staff or other members of the programme is also listed by some authors as a type of an immaterial benefit (e.g. Gwinner et al., 1998), since it stimulates the sense of status in the buyers. According to the research by Bojei et al. (2013, p. 177), the sense of belonging is an important factor for keeping the customers. It is achieved by creating friendly relationships and comfortable atmosphere in a retail store. Keeping the customers is one of the key goals of loyalty programmes, so it is important to determine how important the sense of belonging is to the buyers. The very participation in the programme creates that feeling, and the relations and events in the programme make it stronger. Besides the aforementioned soft benefits, like the preferential treatment, this feeling can be created by providing an image of the programme as the community of the likeminded, by enabling connections, socialisation, and exchange of experiences between the members. Wijaya (2017, p. 195) remarks that customer experience plays a significant role in moderating the effect of self-congruity on customer loyalty. Acceptance by the staff and the retailer via the inclusion of the customer in some business activities, e.g. trying out new products, will also induce the feeling of belonging. In line with the results of the previously mentioned research, we think that it is necessary to do research relating to this statement, and it was therefore necessary to formulate the following hypothesis:

H5: For the buyers, the 'sense of belonging' in loyalty programmes is important.

This research also focused on the respondents who are not members of any loyalty programmes, with the aim of determining the reasons and to provide the retailers with the information on the opinions of the buyers who are not members of any loyalty programme.

In order to achieve the set goals of this article and with the aim of validating the research hypotheses, primary research was conducted. For the purpose of primary research quantitative inferential method was applied and as an instrument for data collection a Google questionnaire was used, whose goal was to find out how important specific components of loyalty programmes are to the customers. The questionnaire was conducted in the Republic of Croatia, during March and April 2017. The questionnaire consisted of 19 questions divided into two parts. The first part consisted of demographic questions. The second part was made of questions and statements compiled in line with the formulated hypotheses, relating to the 
loyalty programmes in retail. The second part was filled out by members of at least one loyalty programme, while respondents who were not members of any loyalty programmes only needed to state the reasons for not participating in loyalty programmes.

For analysing the collected data quantitative research methods were used. To test the research hypothesis $\mathrm{CHI}$ Squaring Independence test well as analysis of variance (ANOVA) were used. This methodology was used because collected data was of ordinal and numerical type. Chi-Square test of independence is used to determine if there is a significant relationship between two nominal (categorical) variables, while the frequency of each category for one nominal variable is compared across the categories of the second nominal variable. With the aim of testing differences in parameter values ANOVA was applied. ANOVA is a statistical method that is used to test differences between two or more means. It is also used to test general rather than specific differences among means.

The population for the research were consumers on the Croatian FCMG market. Data for the sample were collected by using an online Google form questionnaire (CAWI method). Data collection was the result of snowball sampling. For the snowball sampling technique it is characteristic that process begins with the identification of the initial respondents which will provide a further increase in respondents through their network. This method seeks to exploit the effects of the social network of initial respondents that will ensure an increasing number of potential participants in the survey. It differs from the conventional approach to qualitative research, as their primary task is the strategy of target selection (Goodman, 1961: 148). The research sample consisted of 380 respondents of different gender, age and educational background.

\section{RESULTS AND DISCUSSION}

Out of the total of 380 respondents, $66.3 \%$ (252) of them declared they were members of at least one loyalty programme in retail, while the other $33.7 \%(128)$ of the respondents wrote they were not members of any loyalty programme. The research showed that $32 \%$ of the respondents who were not members of any programme thought that the loyalty programmes are too demanding and that rewards are hard to achieve. $30 \%$ of them felt that only a retailer benefits from loyalty programmes. A smaller percentage $(23 \%)$ thought that a lot of personal data is required while entering a programme, and the remaining $15 \%$ listed other reasons, (e.g. no reasons or they were not interested). The model was tested for the influence of control variables (gender, age, education, work status and income) on the tendency of the buyers to participate in consumer goods retail loyalty programmes in the Republic of Croatia.

Table 1 shows the characteristics of those respondents who answered the question about loyalty affirmatively. The respondents evaluated on the 1-5 Likert scale a series of elements considered to form predispositions for the participation in loyalty programmes: program innovation, simplicity, no limitations in the way of using the benefits, no time limitations in using the benefits, relationship with the staff, staff behaviour, the sense of special treatment, retail chains' familiarity with the buying habits of the consumers, entertainment in the programme and the desire to be a part of the community.

The results presented in Table 2 show that gender and education have a statistically significant influence on the probability of entering a specific loyalty programme. Women and individuals with higher education have proved to be more prone to participate in retail 
chains' loyalty programmes. While barely $38.5 \%$ of men were members of a loyalty programme, the share of women was $78.1 \%$ (Table 3 ).

Table 1. Characteristics of the sample

\begin{tabular}{|c|c|c|c|c|c|c|c|c|}
\hline 克 & M & $F$ & $18-24$ & $25-34$ & $34+$ & $\begin{array}{c}\text { LOW/ } \\
\text { SECONDARY } \\
\text { EDUCATION }\end{array}$ & $\begin{array}{l}\text { HIGHER } \\
\text { EDUCA- } \\
\text { TION }\end{array}$ & $\begin{array}{l}\text { HIGH } \\
\text { EDUCA- } \\
\text { TION+ }\end{array}$ \\
\hline$F$ & 42 & 210 & 91 & 94 & 68 & 119 & 48 & 86 \\
\hline$\%$ & 16.7 & 83.3 & 36 & 37.2 & 26,9 & 47 & 19 & 34 \\
\hline & $\begin{array}{l}\text { Undetermined, } \\
\text { retired }\end{array}$ & $\begin{array}{l}\text { Part-time, } \\
\text { fixed-term }\end{array}$ & $\begin{array}{l}\text { Unem- } \\
\text { ployed }\end{array}$ & Student & $<3 k H R K$ & 3-5k HRK & 5-7k HRK & $>7 \mathrm{k} \mathrm{HRK}$ \\
\hline$F$ & 121 & 33 & 28 & 71 & 93 & 57 & 62 & 26 \\
\hline$\%$ & 47.8 & 13 & 11.1 & 28.1 & 39.1 & 23.9 & 26.1 & 10.9 \\
\hline
\end{tabular}

Source: own study.

Table 2. Influence of gender and age regarding participation in loyalty programmes

\begin{tabular}{|c|c|c|c|c|c|}
\hline \multirow{2}{*}{$\begin{array}{c}\text { Participation in } \\
\text { loyalty programms }\end{array}$} & GENDER & \multicolumn{4}{|c|}{ AGE } \\
\cline { 2 - 6 } & Male & Female & $\mathbf{1 8 - 2 4}$ & $\mathbf{2 5 - 3 4}$ & $\mathbf{3 4 +}$ \\
\hline \multirow{2}{*}{ YES } & 42 & 210 & 91 & 94 & 68 \\
\cline { 2 - 6 } & $38.5 \%$ & $78.1 \%$ & $65.5 \%$ & $69.1 \%$ & $66.0 \%$ \\
\hline \multirow{2}{*}{ NO } & 67 & 59 & 48 & 42 & 35 \\
\cline { 2 - 6 } & $61.5 \%$ & $21.9 \%$ & $34.5 \%$ & $30.9 \%$ & $34.0 \%$ \\
\hline $\boldsymbol{X 2}$ & \multicolumn{3}{|c|}{$\mathbf{0 . 0 0 0}$} & \multicolumn{4}{c}{$\mathbf{0 . 7 9 2}$} \\
\hline
\end{tabular}

Source: own study.

Table 3. Influence of education and work status regarding participation in loyalty programmes

\begin{tabular}{|c|c|c|c|c|c|c|c|}
\hline \multirow{2}{*}{ 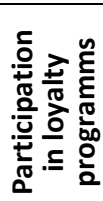 } & \multicolumn{3}{|c|}{ EDUCATION } & \multicolumn{4}{|c|}{ WORK STATUS } \\
\hline & $\begin{array}{l}\text { LOWER AND } \\
\text { SECONDARY } \\
\text { EDUCATION }\end{array}$ & $\begin{array}{l}\text { HIGHER } \\
\text { EXPERTISE }\end{array}$ & $\begin{array}{c}\text { HIGH } \\
\text { EXPERTISE }\end{array}$ & $\begin{array}{c}\text { Indetermi- } \\
\text { nate period, } \\
\text { etired }\end{array}$ & $\begin{array}{l}\text { Part-time, } \\
\text { fixed-term } \\
\text { contract }\end{array}$ & Unemployed & Student \\
\hline \multirow{2}{*}{ YES } & 119 & 48 & 86 & 121 & 33 & 28 & 71 \\
\hline & $57.50 \%$ & $78.70 \%$ & $76.80 \%$ & $65.80 \%$ & $71.70 \%$ & $59.60 \%$ & $70.30 \%$ \\
\hline \multirow{2}{*}{ NO } & 88 & 13 & 26 & 63 & 13 & 19 & 30 \\
\hline & $42.50 \%$ & $21.30 \%$ & $23.20 \%$ & $34.20 \%$ & $28.30 \%$ & $40.40 \%$ & $29.70 \%$ \\
\hline$x^{2}$ & \multicolumn{3}{|c|}{0.000} & \multicolumn{4}{|c|}{0.52} \\
\hline
\end{tabular}

Source: own study.

Based on the results presented in Table 3 and Table 4 it can be concluded that age, work status and the level of income were not significant control variables.

It is evident that buyers deem the relationship with the staff important in the overall evaluation of a loyalty programme. The results of the conducted research show that almost $72 \%$ of the respondents think that the relations with the staff are very or absolutely important. From these results a conclusion can be drawn that the sales staff has a strong influence on buyers' evaluation of the programme, i.e. their satisfaction from the loyalty programme. Also, the average value of the respondents who evaluated the importance of 
the relationship with the staff related to loyalty programmes was $\mu=3.94$, which is statistically significant ( $p=.000$, Table 5 ). In line with this, $\mathrm{H} 1$ : In loyalty programmes the relationship with the sales staff is important to the buyers - is confirmed.

Table 4. Influence of monthly income regarding participation in loyalty programmes

\begin{tabular}{|c|c|c|c|c|}
\hline \multirow{2}{*}{$\begin{array}{c}\text { Participation in } \\
\text { loyalty programms }\end{array}$} & \multicolumn{4}{|c|}{ MONTHLY INCOME } \\
\cline { 2 - 5 } & $\mathbf{< 3 k \text { HRK }}$ & 3-5k HRK & 5-7k HRK & > 7k HRK \\
\hline \multirow{2}{*}{ YES } & 93 & 57 & 62 & 26 \\
\cline { 2 - 5 } & $67.90 \%$ & $5.80 \%$ & $76.50 \%$ & $68.40 \%$ \\
\hline \multirow{2}{*}{ NO } & 44 & 40 & 19 & 12 \\
\cline { 2 - 5 } & $32.10 \%$ & $41.20 \%$ & $23.50 \%$ & $31.60 \%$ \\
\hline $\boldsymbol{X 2}$ & & & & 0.093 \\
\hline
\end{tabular}

Source: own study.

Table 5. Summary research results

\begin{tabular}{|l|c|c|c|c|c|c|}
\hline \multicolumn{1}{|c|}{ Loyalty programmes components } & $\boldsymbol{\mu}$ & $\boldsymbol{P . V .}$ & GENDER & $\boldsymbol{A G E}$ & EDUCATION & INCOME \\
\hline Relationship with the staff H1 & 3.94 & 0.000 & $\mathbf{0 . 0 0 0 2}$ & 0.843 & 0.557 & 0.834 \\
\hline Knowing my buying habits and needs H2 & 3.50 & 0.000 & 0.138 & 0.706 & 0.790 & 0.083 \\
\hline Preferential treatment H3 & 3.66 & 0.000 & 0.090 & 0,696 & 0.036 & 0.041 \\
\hline Fun in loyalty programmes H4 & 3.49 & 0.000 & 0.956 & 0.857 & 0.556 & 400 \\
\hline Being a part of the community H5 & 3.61 & 0.000 & 0.055 & 0.813 & 0.613 & 0.316 \\
\hline
\end{tabular}

Source: own stud.

Further on, the importance of a personalised approach was investigated. The personalised approach to the customer implies that the retailer is familiar with the customer buying habits and needs, and in line with that can approach them on an individual level. They can, for example, send coupons for the products that the customer usually buys, and this approach also includes making connections between the retailer and the customers, most often via sending personalised coupons or birthday cards. The analysis of the results suggests that $55.6 \%$ of the respondents agreed with the statement that a personalised approach has big or absolute importance in loyalty programmes. If we add $25.2 \%$ of the respondents who said it was neither important nor unimportant, the significance of the personalised approach for the buyers is absolutely unquestionable. The average value of the respondents who evaluated the importance of the personalised approach towards the customers in loyalty programmes was $\mu=3.50$, which was also statistically significant $(p=.000$, Table 5). Generally, it can be said that these results are in line with previous research (Omar \& Musa, 2011; Bojei et al., 2013), that also confirmed the importance of a personalised approach to buyers in loyalty programmes. Based on the above-mentioned, H2: For the buyers, personalised approach in loyalty programmes is important is confirmed.

Preferential treatment is one of the soft benefits in loyalty programmes. As all other immaterial benefits, preferential treatment helps the retailer to form connections with the customers. Preferential treatment is very or absolutely important to $60 \%$ of the respondents. Such results can seem very persuasive, especially when added to $23.7 \%$ of those respondents who opted for medium importance. The average value of the respondents who evaluated the importance of the preferential treatment for the buyers was $\mu=3.66$, also of statistical importance $(p=.000$, Table 5$)$. It can be therefore concluded that 
special treatment is important to buyers. The significance of the acquired results is also confirmed by the fact that only $16.3 \%$ of the respondents stated that preferential treatment was not important, or of little importance. In line with that, H3: For the buyers, 'preferential treatment' in loyalty programmes is important is confirmed.

The importance of entertainment to the buyers was proved by the research made by Kim et al. (2013, p. 109), where it was shown that the factor of fun in a loyalty programme is the key driver of loyalty towards a loyalty programme. Fun elements that can be implemented in loyalty programmes are winning games or appropriate contests for the members of loyalty programmes. Many respondents (34.7\%) remained neutral when asked about the importance of fun elements in loyalty programmes, while $48.8 \%$ agreed that they are important and $16.5 \%$ considered them unimportant. Accordingly, H4: Buyers want loyalty programmes with elements of fun is rejected. Nevertheless, although the hypothesis is rejected, due to a large number of the respondents that remained neutral, and the small percentage of them who did not support the element of fun (16.5\%), it is important to implement some elements of fun on the Croatian retail market in order to investigate buyers' opinions on them.

The sense of belonging in buyers is a consequence of the connections made with the staff, other employees of the retailer, and other members of the programme, all related to the atmosphere in a store. It is about positive feelings that should arise from the joint efforts of everybody who is included in the programme. The results of the research on the respondents' attitudes relating to the importance of the sense of belonging in loyalty programmes unmistakably show that it is very or absolutely important for $57.2 \%$ of them, and $27.2 \%$ of the respondents opted for the medium importance. Likewise, the average value of all the respondents who evaluated the importance of the sense of belonging in a loyalty programme was $\mu=3.61$, which is also statistically significant ( $p=.000$, Table 5 ). Bearing in mind the small percentage $(15.7 \%)$ of those respondents who think that the sense of belonging is of little or no importance, it can be confirmed that to the buyers, the sense of belonging is important, so the H5: For the buyers, the 'sense of belonging' in loyalty programmes is important - is confirmed.

The primary aspiration of this research was to point to the significance of some components, so that retailers can review their activities related to these components. Above all, does the retailer undertake specific activities too much or too little? This question especially refers to the soft benefits. Although the research has confirmed that preferential treatment is important to the buyers, every retailer should choose the way of implementing it, i.e. investigate the components that are more or less convenient for specific customers. Namely, some customers can think that it is a great idea that the retailer has access to the information about them, so they could be informed on the deals, be sent coupons and be informed on novelties, while other customers will be more pleased if they are not disturbed much, just an occasional invitation or a card. Besides the guidelines for more successful loyalty programmes, a retailer can get the idea about the implementation of some new elements from this article.

The results of the research largely confirm the authenticity of the previous research, especially on the importance of the quality of the service - the staff in loyalty programmes. It was shown that the importance of the staff in loyalty programmes is very important to the buyers, like in the research by Omar and Musa (2011), where this component occupied the first place in the evaluation of the quality of the service in loyalty programmes. The 
importance of soft benefits in loyalty programmes - personalised approach, preferential treatment, the sense of belonging, was confirmed with this research, in line with previous researches by Bojei (2013) and Huang (2015). Based on the acquired results, this research rejected the hypothesis on the importance of the element of fun in loyalty programmes for the buyers on the Croatian retail market, so the research in this case differs from the one conducted by Kim et al. (2013), where the element of fun was highlighted.

\section{CONCLUSIONS}

The aim of this research was to establish buyers' attitudes towards the specific components of loyalty programmes. The relationship with the staff has proved to be the element of the loyalty programme that is important to buyers on the Croatian market, and the research confirmed that it greatly influences the buyers to stay in a loyalty programme. Within the framework of immaterial rewards, the empirical research was principally focused on: the personalised approach to the buyer, preferential treatment of the buyer, buyer's attitudes to fun elements in loyalty programmes, and the sense of belonging.

The results of the conducted research undoubtedly show that on the fast-moving consumer goods market in Croatia, preferential treatment, personalised approach and the sense of belonging are important to the buyers. Out of those components, most important is the preferential treatment. Buyers' attitudes on the implementation of fun elements point to a certain level of interest, but, nevertheless, half of the respondents remained neutral, so it cannot be claimed that it is what the buyers want. Namely, these are still 'innovations' on the Croatian retail market, and they are novelties in loyalty programmes. The interest of the respondents is evident, but many of them cannot decide. In line with that, it is rational to conclude that the buyers should first be acquainted with the innovations, so they can clearly state their opinions and then their attitudes could be established. Besides the above-mentioned, it is important to note that opinions and attitudes of the buyers will vary according to the location of the retailer, the assortment of goods, etc.

In the theoretical part of the article, special attention was given to the analysis of the influence of loyalty programmes on business dealings of the retailers. The analysed literature, above all, suggests that retailers can improve their business by using loyalty programmes, since they are in a way represented through them. It can be assumed that for the buyer who is satisfied with the loyalty programme, this programme will be a kind of a stimulus for establishing a deeper relationship with the retailer.

Based on the results obtained from the empirical research on the Croatian retail market, conclusions and recommendations for the management can be formulated. Besides, most respondents (31.9\%) who are not members of loyalty programmes think that they are too demanding and the rewards are difficult to get, while $30.4 \%$ think that only retailers profit from the loyalty programmes. The statement that too much personal data is required when entering a loyalty programme is supported by $23 \%$ of the respondents. The other $15 \%$ offered their reasons as to why they do not participate in loyalty programmes. The management should address the stated issues in such a way that they should ensure the availability of the rewards and set realistic thresholds and rules of the participation, so those who are not yet members of a loyalty programme could become willing and motivated. Retailers should also work on giving the information on activities related to the functioning of a loyalty programme, starting 
with the financial side - necessary for its implementation. Such transparency could help to refute common opinions and attitudes about the customers' exploitation which evoke the feelings of fear and rejection towards loyalty programmes. In line with that, for example, Melnyk and Bijmolt (2015, p. 413) recommend that the companies can suppress the feeling of fear related to giving personal data and stimulate the membership, with offering the option of choosing the anonymous and personalised loyalty card. The differences in the research results are not drastic, on the contrary, they are minimal, but it is necessary to draw a line and establish the elements of loyalty programmes that should be real priority for the retailers.

Based on this research, retail companies on the Croatian retail market can get a clear picture of the significance and the role of specific components of loyalty programmes, so they can focus on what is most important to the buyers.

Further research may be conducted about what influences purchase decisions and retailer choice of those consumers who claim not to be loyal to a specific retailer. Further research could also examine what the proportion of loyal customer for each retailer on currently highly dynamic FMCG Croatian retail market is and how important loyalty is in the market success of Croatian retailers.

\section{REFERENCES}

Agudo, J.C., Crespo, A.H., \& Rodríguez del Bosque, I. (2012). Adherence to customer loyalty programmes and changes in buyer behaviour. The Service Industries Journal, 32(8), 1323-1341. https://doi.org/10.1080/02642069.2010.545884

Bakhtieva, E. (2017). B2B digital marketing strategy: a framework for assessing digital touchpoints and increasing customer loyalty based on Austrian heating, ventilation and air conditioning industry companies. Oeconomia Copernicana, 8(3), 463-478.

Bojei, J., Julian, C.C., Che Wel, C.A.B., \& Ahmed, Z.U. (2013). The empirical link between relationship marketing tools and consumer retention in retail marketing. Journal of Consumer Behaviour, 12(3), 171-181. https://doi.org/10.1002/cb.1408

Brashear-Alejandro, T., Kang, J., \& Groza, M.D. (2016). Leveraging loyalty programs to build customer-company identification. Journal of Business Research, 69(3), 1190-1198. https://doi.org/10.1016/j.jbusres.2015.09.014

Breugelmans, E., Bijmolt, T.H.A., Zhang, J., Basso, L.J., Dorotic, M., Kopalle, P., Minnema, A., Mijnlieff, W.J., \& Wünderlich, N.V. (2015). Advancing research on loyalty programs: a future research agenda. Marketing Letters, 26(2), 127-139.

Dorotic, M., Bijmolt, T.H.A., \& Verhoef, P.C. (2012). Loyalty programmes: Current knowledge and research directions. International Journal of Management Reviews, 14(3), 217-237. https://doi.org/10.1111/j.1468-2370.2011.00314.x

Dowling, G.R., \& Uncles, M. (1997). Do Customer Loyalty Programs Really Work? Sloan Management Review, 38(4), 71-82.

Goodman, L.A. (1961). Snowball sampling. The Annals of Mathematical Statistics, 32(1), 148-170. https://doi.org/10.1214/aoms/1177705148

Gwinner, K.P., Gremler, D.D., \& Bitner, M.J. (1998). Relational benefits in services industries: the customer's perspective. Journal of the Academy of Marketing Science, 26(2), 101-114.

Hajdukiewicz, A. (2016). A new approach to customer loyalty programs in the era of digitalization: The example of the Freebee loyalty technology platform. In N. Knego, S. Renko \& B. Knežević (Eds.) Trade perspectives 2016: Safety, security, privacy and loyalty (pp.159-171). Zagreb: Faculty of Economics \& Business. 
Huang, M. (2015). The influence of relationship marketing investments on customer gratitude in retailing. Journal of Business Research, 68(6), 1318-1323.

Julian, C.C., Ahmed, Z.U., Che Wel, C.A.B., \& Bojei, J. (2016). Dynamics of loyalty programs in Malaysian retailing: A strategic marketing perspective. Journal of Transnational Management, 21(3), 101-114. https://doi.org/10.1080/15475778.2016.1192914

Kim, H.Y., Lee, J.Y., Choi, D., Wu, J., \& Johnson, K.K.P. (2013). Perceived Benefits of Retail Loyalty Programs: Their Effects on Program Loyalty and Customer Loyalty. Journal of Relationship Marketing, 12(2), 95-113. https://doi.org/10.1080/15332667.2013.794100

Levy, M., \& Weitz, B.A. (2009). Retailing Management. Boston: McGraw-Hill.

Meyer-Waarden, L., Benavent, C., \& Castéran, H. (2013). The effects of purchase orientations on perceived loyalty programmes' benefits and loyalty. International Journal of Retail \& Distribution Management, 41(3), 201-225. https://doi.org/10.1108/09590551311306255

Melnyk, V., \& Bijmolt, T. (2015). The effects of introducing and terminating loyalty programs. European Journal of Marketing, 49(3/4), 398-419. https://doi.org/10.1108/EJM-12-2012-0694

Noble, S.M., Esmark, C.L., \& Noble, C.H. (2014). Accumulation versus instant loyalty programs: The influence of controlling policies on customers' commitments. Journal of Business Research, 67(3), 361-368. https://doi.org/10.1016/j.jbusres.2013.01.002

Omar, N.A., Alam, S.S., Abdul Aziz, N., \& Nazri, M.A. (2011). Retail Loyalty Programs in Malaysia: The Relationship of Equity, Value, Satisfaction, Trust, and Loyalty among Cardholders. Journal of Business Economics and Management, 12(2), 332-352.

Rundle-Thiele, S. (2005). Exploring loyal qualities: assessing survey-based loyalty measures. Journal of Services Marketing, 19(7), 492-500. https://doi.org/10.1108/08876040510625990

Omar, N.A., Aniza, C., Norzalita, C.W., Syed, A.A., \& Alam, S. (2013). Investigating the structural relationship between loyalty programme service quality, satisfaction and loyalty for retail loyalty programmes: evidence from Malaysia. Measuring Business Excellence, 17(1), 33-50. https://doi.org/10.1108/13683041311311356

Omar, N.A., \& Musa, R. (2011). Measuring service quality in retail loyalty programmes (LPSQual). International Journal of Retail \& Distribution Management, 39(10), 759-784. https://doi.org/10.1108/09590551111162257

Solarova, P. (2015). Loyalty Programmes of Selective Grocery Retailers in the Czech Republic. Acta Universitatis Agriculturae et Silviculturae Mendelianae Brunensis, 63(2), 617-625.

Sreejesh S., Abhigyan, S., \& Sudeepta, P. (2016). Examining the roles played by a store satisfaction-love framework in shaping the influence of store loyalty programs. Management $R e-$ search Review, 39(8), 879-898.

Szwajca, D. (2016) Corporate Reputation and Customer Loyalty as the Measures of Competitive Enterprise Position - Empirical Analyses on the Example of Polish Banking Sector. Oeconomia Copernicana, 7(1), 91-106.

Xie, K.L., \& Chen, C. (2013). Progress in Loyalty Program Research: Facts, Debates, and Future Research. Journal of Hospitality Marketing and Management, 22(5), 463-489.

Vesel, P., \& Zabkar, V. (2009). Managing customer loyalty through the mediating role of satisfaction in the DIY retail loyalty program. Journal of Retailing and Consumer Services, 16(5), 396-406. https://doi.org/10.1016/j.jretconser.2009.05.002

Wijaya, A.P. (2017). Role of Experience in Customer Self-Congruity to Maintaining Loyalty: A Study on Fashion Store. Entrepreneurial Business and Economics Review, 5(3), 189-198. https://doi.org/10.15678/EBER.2017.050310 


\section{Authors}

The contribution share of authors is equal and amounted to $1 / 3$ each of them.

\section{Ivan Kovac}

Assistant Professor at the Department of Trade, University of Zagreb. PhD in Economics (2009). $\mathrm{He}$ is teaching courses at undergraduate and graduate level at Faculty of Economics and Business Zagreb. His research interests include supply chain management, entrepreneurship and innovations in trade, retailing, distribution channels and logistics systems.

Correspondence to: Ivan Kovac, PhD, University of Zagreb, Faculty of Economics and Business, Department of Trade; Trg J. F. Kennedy 6, 10000 Zagreb, Croatia; e-mail: ivan.kovac@efzg.hr

\section{Dora Naletina}

Assistant Professor at the Department of Trade at the Faculty of Economics and Business in Zagreb. $\mathrm{PhD}$ in Economics (2016). She is teaching courses at undergraduate and graduate level at Faculty of Economics and Business Zagreb. Her research interests include supply chain management, sharing economy, transportation management, transport policy, transport insurance and green transport.

Correspondence to: Dora Naletina, PhD; University of Zagreb, Faculty of Economics and Business, Department of Trade; Trg J. F. Kennedy 6, 10000 Zagreb, Croatia; e-mail: dora.naletina@efzg.hr

\section{Dunja Brezovic}

Dunja Brezovic graduated from the Faculty of Economics and Business in Zagreb at the Department of Trade and became MA. She wants to develop more training skills and knowledge in supply chain management and consumer protection. She has work experience in sales and promotions.

Correspondence to: Dunja Brezovic, MA; e-mail: dunjabrezovic@gmail.com

\section{Acknowledgements and Financial Disclosure}

The authors would like to thank to all respondents who have participated in primary research. As well, authors would like to thank the anonymous referees for their usefull comments which have increased the value of this paper.

\section{Copyright and License}

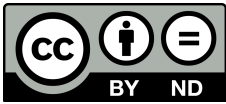

This article is published under the terms of the Creative Commons

Attribution - NoDerivs (CC BY-ND 4.0) License http://creativecommons.org/licenses/by-nd/4.0/

\section{Published by the Centre for Strategic and International Entrepreneurship - Krakow, Poland}


